\title{
Preparation and preliminary application of monoclonal antibodies to the receptor binding region of Clostridium difficile toxin B
}

\author{
WEI CHEN, WEN-EN LIU, YAN-MING LI, SHAN LUO and YI-MING ZHONG \\ Department of Clinical Laboratory, Xiangya Hospital of Central South University, Changsha, Hunan 410008, P.R. China
}

Received October 25, 2014; Accepted July 21, 2015

DOI: $10.3892 / \mathrm{mmr} .2015 .4369$

\begin{abstract}
A previous nationwide Chinese epidemiological study revealed through isolation of $\mathrm{A}^{-} \mathrm{B}^{+}$Clostridium difficile strains, which produce toxin B (TcdB), but not toxin A TcdA, that the strains are widespread and more frequent in east Asian countries,. The development of a process capable of detecting $\mathrm{TcdB}$ is required in microbiological laboratories in order to facilitate the control of the $\mathrm{A}^{-} \mathrm{B}^{+} C$. difficile strains, however, no diagnostic reagents have been developed to date. The aim of the present study was to prepare monoclonal antibodies (mAbs) targeting the receptor binding region of TcdB (CDB3), and to establish a double-antibody sandwich enzyme-linked immunosorbent assay (ds-ELISA), which can be used for the diagnosis of $C$. difficile infection. The recombinant protein, glutathione $\mathrm{S}$ transferase (GST)-CDB3 was expressed and purified using an Escherichia coli system. BALB/c mice were immunized with GST-CDB3 recombinant protein. A hybridoma technique was used for the production of anti-CDB3 mAb. The hybridoma clones were then screened using indirect ELISA, and anti-CDB3 $\mathrm{mAb}$ was produced in the ascites of the BALB/c mice. Isotyping of anti-CDB3 mAb was performed using an SBA Clonotyping system/horseradish peroxidase (HRP) ELISA kit. Protein G affinity chromatography was used for purification of anti-CDB3 mAbs, and the titer and specificity of the anti-CDB3 mAbs were assessed using indirect ELISA and western blot analysis, respectively. The ds-ELISA was established using HRP-labeled anti-CDB3 mAbd, which were used to detect TcdB clinically in diarrhea stools. A total of five stable hybridoma cell clones (1E7B, 1F8D3, 2F8A6, 3B6F1 and $4 \mathrm{~A} 4 \mathrm{G} 2$ ) producing anti-CDB3 $\mathrm{mAb}$ were established. The results of the present study indicated that the immunoglobulin $(\mathrm{Ig}) \mathrm{G}$ isotype was predominant, as $1 \mathrm{E} 7 \mathrm{~B} 2 \mathrm{IgG} 1(\lambda), 2 \mathrm{~F} 8 \mathrm{~A} 6$ $\operatorname{IgG} 2 \mathrm{a}(\kappa)$ and 4A4G2 IgG1 ( $)$. In addition, the highest titer of anti-CDB3 mAb (2F8A6 and 4A4G2) was 1:51,200. Western
\end{abstract}

Correspondence to: Dr Wen-En Liu, Department of Clinical Laboratory, Xiangya Hospital of Central South University, 87 Xiangya Road, Changsha, Hunan 410008, P.R. China

E-mail: liuwenen@gmail.com

Key words: Clostridium difficile, CDB3, anti-CDB3 monoclonal antibody, double-antibody sandwich ELISA blotting revealed that the $2 \mathrm{~F} 8 \mathrm{~A} 6$ and $4 \mathrm{~A} 4 \mathrm{G} 2 \mathrm{mAbs}$ recognized the CDB3 protein specifically. Following anti-CDB3 mAb (4A4G2) HRP-labeling, the optimal working concentration was confirmed to be 1:400, and the concentration of coated antibody (2F8A6) was $20 \mu \mathrm{g} / \mathrm{ml}$. The sensitivity of the ds-ELISA was $73.33 \%$ for the $\mathrm{A}^{+} \mathrm{B}^{+}$toxigenic $C$. difficile strains, and $86.67 \%$ for the $\mathrm{A}^{-} \mathrm{B}^{+}$toxigenic $C$.difficile strains, with a specificity of $100 \%$ for all. In conclusion, the present study successfully developed novel mAbs specific to CDB3, and developed a ds-ELISA kit with high specificity and sensitivity for the rapid detection of TcdB. This offers a useful tool for the diagnostic assessment of TcdB.

\section{Introduction}

Clostridium difficile was first detected in the fecal flora of healthy newborns in the mid-1930s (1) and considered to be non-pathogenic until identified as the primary cause of pseudomembranous colitis in 1978 (2). C. difficile is a gram-positive anaerobic, spore-forming bacterium, and accounts for $15-30 \%$ of all episodes of antibiotic-associated diarrhea (AAD) and $95-100 \%$ of cases of pseudomembranous colitis (PMC) $(3,4)$. The morbidity, mortality and relapse rates of the diseases caused by $C$. difficile have markedly increased in hospital and community settings due to the spread of hypervirulent strains, including BI/NAP1/027, restriction endonuclease analysis type BI, North American pulsed-field gel electrophoresis type 1 and polymerase chain reaction ribotype $027(5,6)$, and due to the improper administration of antibiotics in the past decade $(7,8)$. Based on several reports from the US, Canada and Europe, the incidence of $C$. difficile infection (CDI) has increased between 2- and 4-fold in the past decade, particularly in elderly patients exposed to health care settings, including long-term care facilities and hospitals (9-11). Children and peripartum females, previously described as low risk populations for CDI, now show increased incidence (12). CDI-induced mortality rates have markedly increased between 3,000/year in 1999-2000 and 14,000/year in 2006-2007 (13). The risk of recurrence following an initial episode of CDI is $20 \%$, which increases up to $60 \%$ following a third episode (14). CDI remains the most common cause of hospital-acquired diarrhea, with the number of hospitalized patients diagnosed with any CDI discharge increasing between 139,000 in 2000 and 336,600 in 2009, at a cost of $\$ 1,000,000,000$ annually (15). In addition, CDI has surpassed methicillin-resistance Staphylococcus aureus as 
the most common hospital and healthcare facility-associated infection (16). C. difficile toxin A (TcdA), an enterotoxin, and C. difficile toxin B (TcdB), a cytotoxin, are the major virulence factors of $C$. difficile, and contribute to its pathogenicity by inducing mucosal inflammation and diarrhea (17). In addition to these toxins, $C$. difficile may produce a number of other putative virulence factors, including $C$. difficile binary toxin (CDT), fibronectin binding protein A, fimbriae, S-layer protein $\mathrm{A}, \mathrm{Cwp} 84$ cysteine protease and $\mathrm{Cwp} 66$ and $\mathrm{CwpV}$ adhesions (17).

A previous nationwide epidemiological study demonstrated that isolation of an $\mathrm{A}^{-} \mathrm{B}^{+}$Clostridium $(C$.) difficile strain, which produces TcdB, but not TcdA, has spread widely (18-20) and is more frequent in east Asian countries $(8,19,21-23)$. Initially, TcdA was considered to be the most important factor responsible for diarrheal disease (20), however, several observations in variety of animal models have demonstrated this is not always the case. In hamsters and mice, intragastric administration of TcdA, but not TcdB, resulted in intestinal fluid accumulation, diarrhea, hemorrhage and mortality (24). However, previous reports have demonstrated that $\mathrm{A}^{-} \mathrm{B}^{+} C$. difficile strains can lead to similar symptoms, ranging between mild diarrhea and severe pseudomembranous colitis $(25,26)$. Diagnosis of CDI via the detection of TcdB is required in microbiological laboratories in order to control these strains of $C$. difficile, however, to date no such diagnostic reagents have been developed in China. Therefore, rapid diagnosis of $C$. difficile in patients with AAD and PMC is important for guiding the treatment and control of nosocomial infection spread. The primary objective of the present study was to establish hybridoma cell lines stably secreting anti-CDB3 monoclonal antibodies (mAbs), which may be used for the development of double-antibody sandwich (ds)-ELISA. In addition, the present study aimed to detect TcdB in diarrhea stools using ds-ELISA, in order to establish an effective method for the future diagnosis of CDI.

\section{Materials and methods}

Ethical statement. Six female BALB/c mice (age, 6-8 weeks old; weight, $\sim 20 \mathrm{~g}$ ) were purchased from the Laboratory Animal Center of the Central South University (Changsha, China) and housed under pathogen-free conditions at $18-28^{\circ} \mathrm{C}$, $40-70 \%$ humidity with free access to standard chow and water. All experiments were performed according to the guidelines of the Animal Ethics Committee of the Central South University. The mice were sacrificed using rapid cervical dislocation to minimize animal suffering.

Expression of glutathione $S$ transferase (GST)-CDB3 recombinant protein. The recombinant plasmid pGEX-4T-1-CDB3 of Escherichia coli BL21 (DE3) was constructed in the Clinical Laboratory in Xiangya Hosipital of Central South University. It was transformed into an BL21(DE3) competent strain (American Type Culture Collection, Manassas, VA, USA), and the E. coli strains was induced. The optimal expression of recombinant proteins was achieved by regulating the concentration of bacteria prior to induction [optical density (OD), 600], along with the induction temperature, induction time and the concentration of isopropyl- $\beta$-D-thiogalactopyran oside (IPTG; Sigma-Aldrich, St. Louis, MO, USA), details of which are shown in Table I. Following induction, the bacteria were harvested and centrifuged at $4^{\circ} \mathrm{C}$ for $15 \mathrm{~min}$ at $4,449 \mathrm{x} \mathrm{g}$, and the pellet was resuspended in lysis buffer (Beijing Donglinchangsheng Biotechnology Co., Ltd., Beijing, China) containing 0.15 M NaCl, 0.05 M Tris-HCl, 0.1\% SDS (Beijing Donglinchangsheng Biotechnology Co., Ltd.), $1 \%$ Triton X-100, $1 \%$ sodium deoxycholate ( $\mathrm{pH} 7.2$ ), followed by lysis by sonication in ice and centrifugation at $4^{\circ} \mathrm{C}$ for $10 \mathrm{~min}$ at $10,012 \mathrm{x} \mathrm{g}$. $C$. difficile strains expressing the GST-CDB3 were also grown, as described above. The expression of the GST-CDB3 recombinant protein was analyzed using 10\% SDS-PAGE. The SDS-PAGE gel was placed in Coomassie Brilliant Blue dye (Sangon Biotech, Co., Ltd., Shanghai, China) overnight in room temperature,then washed with distilled water three times.

Purification and identification of recombinant protein GST-CDB3. The GST-CDB3 recombinant protein was purified using a GST Sefinose ${ }^{\mathrm{TM}}$ kit (Sangon Biotech, Co., Ltd.) and dialyzed in $1 \mathrm{X}$ phosphate-buffered saline (PBS) at $4^{\circ} \mathrm{C}$ overnight, prior to being condensed to a high concentration. The recombinant protein concentration was determined using a Bicinchoninic Acid (BCA) Protein Assay kit (Thermo Fischer Scientific, Inc., Waltham, MA, USA) according to the manufacturer's instructions. The expression of the recombinant protein was analyzed using western blotting, as previously described (27). Briefly, the affinity purified recombinant GST-CDB3 protein was incubated at $72^{\circ} \mathrm{C}$ for $10 \mathrm{~min}$ in $1 \mathrm{X}$ NuPage SDS loading buffer (Beijing Donglinchangsheng Biotechnology Co., Ltd.), prior to being separated by $10 \%$ SDS-PAGE under native and denaturing conditions, and then transferred onto a nitrocellulose membrane (EMD Millipore, Billerica, MA, USA). Following blocking with $5 \%$ fat-free milk at $37^{\circ} \mathrm{C}$ for $2 \mathrm{~h}$, the membrane was incubated with mouse anti-GST monoclonal primary antibody $(1: 2,000$; P09211; EMD Millipore) at $37^{\circ} \mathrm{C}$ for $2 \mathrm{~h}$, followed by incubation with polyclonal horseradish peroxidase (HRP)-conjugated goat anti-mouse secondary antibody (1:1,000; M8645; Sigma-Aldrich) at $37^{\circ} \mathrm{C}$ for $1 \mathrm{~h}$. Between each incubation step, the membranes were washed five times with PBS and $0.2 \%$ Tween 20 (PBST; Beijing Donglinchangsheng Biotechnology Co., Ltd.). The bands were visualized using an enhanced chemiluminescence (ECL) system (Pierce Biotechnology, Inc., Rockford, IL, USA).

Immunization of mice. BALB/c mice were used for hybridoma production, as previously described (28). Briefly, 8-week-old female BALB/c mice were intraperitoneally injected three times with $50 \mu \mathrm{g}$ purified GST-CDB3 recombinant protein at 2 week intervals. Complete and incomplete Freund's adjuvant (1:1; Sigma-Aldrich) was used to emulsify the protein for the first and subsequent immunizations. At 10 days following the third immunization, ELISA (Sangon Biotech, Co., Ltd.) was performed, as previously described (29), to confirm that the serum contained antibodies targeting recombinant protein GST-CDB3, and to detect the antibody titer of mouse serum (using the tail vein procedure). Recombinant protein GST-CDB3 was used as a coating antigen, $1 \%$ BSA-PBS as a blocking solution, mouse serum as the primary antibody, and HRP-conjugated goat anti-mouse immunoglobulin 
Table I. L9(34) orthogonal test for the optimal expression of recombinant proteins.

\begin{tabular}{lcccc}
\hline Level & $\begin{array}{c}\text { Concentration } \\
\text { IPTG }(\mathrm{mmol} / \mathrm{l})\end{array}$ & Induction time $(\mathrm{h})$ & $\begin{array}{c}\text { Concentration of } \\
\text { bacteria (OD 600) }\end{array}$ & $\begin{array}{c}\text { Induction } \\
\text { temperature }\left({ }^{\circ} \mathrm{C}\right)\end{array}$ \\
\hline 1 & 0.6 & 10 & 0.6 & 20 \\
2 & 0.8 & 12 & 0.8 & 30 \\
3 & 1.0 & 16 & 1.0 & 37 \\
\hline
\end{tabular}

IPTG, isopropyl- $\beta$-D-thiogalactopyranoside; OD, optical density.

(Ig) G polyclonal antibodies (1:3,000; Sigma-Aldrich) as the secondary antibody. The mouse with the highest titer specific for GST-CDB3, determined using indirect ELISA, was then administered with $100 \mu \mathrm{g}$ recombinant protein GST-CDB3 without adjuvant 1 week later. Subsequently, 3 days after the last immunization, the spleen was removed and macerated to obtain B lymphocytes, and then washed twice with RPMI-1640 medium (Gibco Life Technologies, Carlsbad, CA, USA).

Hybridoma production. Myeloma cells and spleen lymphocytes were prepared for fusion, as previously described (30). The SP2/0 mouse myeloma cell line (Cancer Research Laboratory, Central South University) in the logarithmic growth phase and with good morphological appearance was used as a fusion partner, the SP $2 / 0$ cells were cultured in $10 \%$ fetal bovine serum (FBS; GE Healthcare Life Sciences, Logan, UT USA) and RPMI-1640 medium at $37^{\circ} \mathrm{C}$ in an atmosphere containing $5 \% \mathrm{CO}_{2}$, prior to treatment with 8-azaguanine (Sigma-Aldrich). The feeder cells of the peritoneal macrophages were collected from normal BALB/c mice by peritoneal washing with RPMI-1640 medium supplemented with hypoxanthine $\left(1 \times 10^{4} \mathrm{M}\right)$, aminopterin $\left(4 \times 10^{7} \mathrm{M}\right)$ and thymidine $\left(1.6 \times 10^{5} \mathrm{M}\right.$; Sigma-Aldrich) and seeded into 96 -well plates 1 day prior to fusion. The splenic lymphocytes and SP2/0 cells were fused at a ratio of 5-10:1. This protocol involved the incubation of the cells in $1 \mathrm{ml} 50 \%$ (w/w) polyethylene glycol/dimethylsulfoxide 3350 (Sigma-Aldrich) at $37^{\circ} \mathrm{C}$ for $1 \mathrm{~min}$, followed by washing with RPMI-1640 medium for $5 \mathrm{~min}$. The hybridomas were seeded into 96-well plates containing the feeder cells and screened using hypoxanthine-aminopterin-thymidine medium. Growth of the hybridomas was regularly observed by an optical microscope (BIO500 PH; Olympus, Tokyo, Japan).

Screening of positive clones and cloning. At 2 weeks following fusion, the cell clones producing anti-CDB3 antibody were screened and identified by indirect ELISA, using the $(0.89 \mathrm{mg} / \mathrm{ml})$ GST-CDB3 recombinant protein and $1.21 \mathrm{mg} / \mathrm{ml}$ GST protein as coating antigens, $1 \%$ BSA-PBS as a blocking solution, the supernatant of each hybridoma cell clone as the primary antibody, and HRP-conjugated goat anti-mouse IgG polyclonal antibodies (1:3,000; Sigma-Aldrich) as the secondary antibody. The optical density (OD) was read at $450 \mathrm{~nm}$ using a microplate reader (Tianshi Technologies, Co., Ltd., Beijing, China and considered positive when the ratio of OD450 experimental to OD450 control was greater than three-fold. The wells, which were positive for the GST-CDB3 recombinant protein, but negative for GST protein were considered positive, and were sub-cloned using limiting dilution, as previously described (31). Further cloning was performed between three and five times in hypoxanthine-thymidine medium (Sigma-Aldrich) for 2 weeks until all selected hybridomas were positive. Finally, the positive clones in the 96-well plates were transferred into 24-well plates in RPMI-1640 medium supplemented without FBS. The strain of hybridoma cells, which established stable growth with the highest positive expression was selected, expanded and preserved at $-70^{\circ} \mathrm{C}$.

Preparation and titer determination of anti-CDB3 $m A b$. The production of hybridomas from ascitic fluid was performed, as previously described by Harlow et al (31). The BALB/c mice were intraperitoneally injected with $0.5 \mathrm{ml}$ incomplete Freund's adjuvant. After 7 days, the mice were intraperitoneally injected with $5 \times 10^{6}$ hybridoma cells diluted in D-Hank's buffered solution (Sigma-Aldrich), which exhibited optimal results following indirect ELISA. The ascitic fluid was collected after 2 weeks and centrifuged for $5 \mathrm{~min}$ at $2,780 \mathrm{x}$ g to remove cellular deposition and other sediments. The anti-CDB3 $\mathrm{mAb}$ supernatant was then diluted into a series of gradients (1:100, 1:200, 1:400, 1:800, 1:1,600, 1:3,200, 1:6,400, 1:12,800, $1: 25,600,1: 51,200,1: 102,400$ and 1:204,800), and indirect ELISA was performed using recombinant protein GST-CDB3 as a coating antigen, $1 \%$ BSA-PBS as a blocking solution, the serial dilutions of supernatant as the primary antibody, and HRP-conjugated goat anti-mouse IgG polyclonal antibodies (1:3,000; Sigma-Aldrich) as the secondary antibody, in order to detect the titer of anti-CDB3 $\mathrm{mAb}$. The OD was read at $450 \mathrm{~nm}$.

Isotype determination and purification of anti-CDB3 $m A b$. The antibody isotyping of anti-CDB3 $\mathrm{mAb}$ was performed using an SBA Clonotyping system/HRP ELISA kit (SouthernBiotech, Birmingham, AL, USA) containing goat anti-mouse $\operatorname{IgG} 1, \operatorname{IgG} 2 \mathrm{a}, \operatorname{IgG} 2 \mathrm{~b}, \operatorname{IgG} 3, \operatorname{Ig} \mathrm{A}, \operatorname{IgM}, \operatorname{Ig} \kappa$ and $\operatorname{Ig} \lambda$, according to the manufacturer's instructions. The anti-CDB3 IgG antibodies $(5 \mathrm{ml})$ were added with an equivalen volume of precooled ammonium sulfate overnight in $4^{\circ} \mathrm{C}$, and then centrifuged at $4^{\circ} \mathrm{C}$ for $15 \mathrm{~min}$ at $1,738 \mathrm{x}$ g. The supernatant was decanted, and the precipitation was solubilized in PBS $(0.02 \mathrm{M} ; 5 \mathrm{ml})$ and purified using Protein $\mathrm{G}$ affinity chromatography (GE Healthcare Life Sciences), according to the manufacturer's instructions. The positive components confirmed by indirect ELISA were dialyzed and condensed to a high concentration. Reduction was performed using 
mercaptoethanol (Sigma-Aldrich) and separation was performed using 10\% SDS-PAGE. Concentration was determined using a BCA Protein Assay kit.

Determination of affinity using ELISA. The present study determined affinity levels using ELISA, as previously described (32). Briefly, ELISA plates pre-coated with $5 \mu \mathrm{g} / \mathrm{ml}$ GST-CDB3 recombinant protein were blocked with $2 \%$ FBS at $37^{\circ} \mathrm{C}$ for $2 \mathrm{~h}$. Serial dilutions of the purified $\mathrm{mAb}$ were incubated at $37^{\circ} \mathrm{C}$ for $2 \mathrm{~h}$. The plates were then rinsed and incubated with HRP-conjugated goat anti-mouse IgG polyclonal antibodies $(1: 3,000)$ at $37^{\circ} \mathrm{C}$ for $1 \mathrm{~h}$. OD was measured at $450 \mathrm{~nm}$ and curves were constructed using the OD450 values obtained from the serial dilutions of the purified $\mathrm{mAb}$, in order to determine the relative affinity.

Western blot analysis of anti-CDB3 mAb specificity. The GST-CDB3 recombinant protein was cleaved using thrombin (Sigma-Aldrich) and separated using 10\% SDS-PAGE. The proteins were transferred onto a nitrocellulose membrane by electroblotting, prior to being blocked with $5 \%$ fat-free milk at $37^{\circ} \mathrm{C}$ for $2 \mathrm{~h}$. The membrane was incubated with purified anti-CDB3 $\mathrm{mAb}(1: 1,000)$ overnight at $4^{\circ} \mathrm{C}$. Following three washes with PBST, the membrane was incubated with HRP-conjugated goat anti-mouse IgG polyclonal antibodies (1:1,000; Sigma-Aldrich) in $37^{\circ} \mathrm{C}$ for $1 \mathrm{~h}$. Following further washing the membrane was visualized using an ECL system.

Conjugation of $m A b$ to HRP. The conjugation of $\mathrm{mAb}$ to HRP was performed, as previously described (33). A total of $2.6 \mathrm{mg}$ HRP dissolved in $1.0 \mathrm{ml}$ water and $0.1 \mathrm{ml}$ sodium periodate solution $(0.1 \mathrm{~mol} / \mathrm{l})$ were combined, stirred for $20 \mathrm{~min}$, and dialyzed in $1 \mathrm{mM}$ sodium acetate buffer (Sangon Biotech, Co., Ltd.; $\mathrm{pH} 4.4)$ overnight at $4^{\circ} \mathrm{C}$. A total of $0.5 \mathrm{ml}(0.16 \mathrm{M})$ was subsequently added to the solution and stirred at $4^{\circ} \mathrm{C}$ for $1 \mathrm{~h}$. A total of $6 \mathrm{mg}$ monoclonal 4A4G2 in $1 \mathrm{ml}$ sodium carbonate buffer $(0.01 \mathrm{M}, \mathrm{pH} 9.6)$ was added and stirred for $2 \mathrm{~h}$. A total of $0.1 \mathrm{ml}$ sodium borohydride solution $(4 \mathrm{mg} / \mathrm{ml})$ was added and dialyzed in $0.02 \mathrm{M}$ PBS ( $\mathrm{pH} 7.2$ ) overnight at $4^{\circ} \mathrm{C}$, then precipitated by the addition of equal volumes of $100 \%$ ammonium sulfate $\left(4^{\circ} \mathrm{C}, 4 \mathrm{~h}\right)$, prior to centrifugation at $3,000 \mathrm{xg}$ for 5 min, dialyzed against $0.01 \mathrm{M}$ PBS (pH 7.4) overnight at $4^{\circ} \mathrm{C}$, and stored at $4^{\circ} \mathrm{C}$ following dilution with $500 \mathrm{ml} / 1$ glycerol (1:1).

Establishment and optimization of $d s$-ELISA. A ds-ELISA for TcdB was established using 4A4G2 as a HRP-labeled mAb and 2F8A6 as a capture mAb. A chessboard titration method was designed to examine the optimal working concentration of capture antibody and HRP-labeled mAb. Briefly, a 96-well immunoplate was coated with purified anti-CDB3 mAb (2F8A6; concentrations, $20 \mu \mathrm{g} / \mathrm{ml}, 10 \mu \mathrm{g} / \mathrm{ml}, 5 \mu \mathrm{g} / \mathrm{ml}$, $2.5 \mu \mathrm{g} / \mathrm{ml}, 1.25 \mu \mathrm{g} / \mathrm{ml}$ and $0.625 \mu \mathrm{g} / \mathrm{ml}$ ) in $0.05 \mathrm{M} / 1$ carbonate buffer (pH 9.6) overnight at $4^{\circ} \mathrm{C}$. Following blocking with $200 \mu 12 \%$ BSA-PBS overnight at $4^{\circ} \mathrm{C}$, the plate was washed five times in PBST, and $100 \mu 1$ serial dilutions of GST-CDB3 recombinant protein in PBS were added to each well and incubated at $37^{\circ} \mathrm{C}$ for $2 \mathrm{~h}$, followed by a further five washes. At total of $100 \mu \mathrm{l}$ diluted HRP-conjugate anti-CDB3 mAb (1:50, 1:100, $1: 200,1: 400,1: 800,1: 1,600,1: 3,200,1: 6,400$ and 1:12,800; detecting antibody) was subsequently added, and the plates were incubated at $37^{\circ} \mathrm{C}$ for $1 \mathrm{~h}$. The plates were then washed and incubated at $37^{\circ} \mathrm{C}$ for $30 \mathrm{~min}$ in the dark, following which then the OD450 was measured.

Stool sample collection. This study was conducted at, and approved by, the Xiangya Hospital of Central South University (Hunan, China) between June 2011 and November 2012. Patients with diarrhea were enrolled which was defined as more than three loose watery stool passages per day, on consecutive days or six times within $36 \mathrm{~h}$. CDI was diagnosed when the Clostridium difficile was isolated from stool culture and identified by API20A (BioMerieux, Marcy l'Etoile, France), the Clostridium difficile isolates were also positive for toxin genes (tcdA, tcdB) as shown by multiplex PCR. The non-CDC group was defined as a group of patients who did not have diarrhea or had diarrhea but were negative for toxin $\mathrm{A} / \mathrm{B}$.

Analysis of clinical stool samples using ds-ELISA. A total of 45 diarrhea stool samples, including 15 samples containing $\mathrm{A}^{+} \mathrm{B}^{+}$toxigenic $C$. difficile, 15 samples containing $\mathrm{A}^{+} \mathrm{B}^{+}$toxigenic $C$. difficile and 15 samples negative for $C$. difficile, were determined using anaerobic toxigenic culture. Briefly, selective enrichment culture for $C$. difficile was performed, and the levels of TcdA, TcdB, CDTA, CDTB were determined using polymerase chain reaction (PCR). All experimental procedures and specimen collections were approved by the Ethics Committee of the Xiangya Hospital of Central South University. The expression levels of TcdB in the stool samples were analyzed using the ds-ELISA technique, as described above.

Fecal culture. Each stool sample $(2 \mathrm{ml})$ was added to an equal volume of absolute ethanol, mixed and left at room temperature for $1 \mathrm{~h}$, then centrifuged $(4,449 \times \mathrm{g} / 10 \mathrm{~min})$ and the pellet was inoculated on selective Clostridium difficile Moxalactam-Norfloxacin-Taurocholate agar (CDMN-TA; Oxoid Ltd., Cambridge, UK) supplemented with $7 \%$ horse blood after alcohol shock (10), and incubated at $35 \pm 2{ }^{\circ} \mathrm{C}$ in an anaerobic atmosphere (85\% nitrogen, 10\% hydrogen and 5\% carbon dioxide) for $48 \mathrm{~h}$. Suspect Clostridium difficile colonies were subcultured and identified as Clostridium difficile on the basis of their morphology on agar plates and by Gram staining as well as the characteristic odor. In addition, oxygen resistance experiments were conducted on specific colonies and confirmed by API 20A (BioMerieux). The demonstration of toxin production was conducted by multiplex PCR for the toxin genes (tcdA and tcdB) or a positive toxin assay using the VIDAS ${ }^{\circledR}$ Clostridium difficile Toxin A \& B (BioMerieux, France). Strains were stored at $-80^{\circ} \mathrm{C}$ in cryobank tubes until further testing.

Multiplex PCR. Toxin gene DNA was isolated from colonies of Clostridium difficile using a DNeasy blood and tissue kit (Qiagen, Hilden, Germany) according to the manufacturer's instructions. All isolates were tested for the presence of tcdA, tcdB, cdtA and cdtB genes. The oligonucleotide primers used are shown in Table II. The amplification reactions were performed in $25 \mu \mathrm{l}$ final volume containing $12.5 \mu \mathrm{l}$ Taq PCR Master mix (2X; Beijing Tiangen Biotech Co., Ltd., Beijing, 
Table II. Primer sequences of oligonucleotides was used for conventional PCR.

\begin{tabular}{lllc}
\hline PCR product & Primer & \multicolumn{1}{c}{ Sequence (5'-3') } & Fragment length (bp) \\
\hline tcdA & NK1 & 5-GGACATGGTAAAGATGAATTC-3 & 546 \\
tcdB & NK2 & 5-CCCAATAGAAGATTCAATATTAAGCTT-3 & 204 \\
& NK104 & 5-GTGTAGCAATGAAAGTCCAAGTTTACGC-3 & 375 \\
cdtA & NK105 & 5-CACTTAGCTCTTTGATTGCTGCACCT-3 & 510 \\
cdtB & Cdta pos & 5-TGAACCTGGAAAAGGTGATG-3 & \\
& Cdta rev & 5-AGGATTATTTACTGGACCATTTG-3 & \\
\hline
\end{tabular}

PCR, polymerase chain reaction.

Table III. Polymerase chain reaction conditions.

\begin{tabular}{|c|c|c|c|c|c|c|}
\hline \multirow[b]{2}{*}{$\begin{array}{l}\text { PCR } \\
\text { product }\end{array}$} & \multicolumn{6}{|c|}{ Reaction conditions } \\
\hline & $\begin{array}{c}\text { Initial enzyme } \\
\text { activation }\end{array}$ & Cycles & Denaturation & Annealing & Elongation & $\begin{array}{c}\text { Final } \\
\text { elongation }\end{array}$ \\
\hline $\operatorname{tcd} \mathrm{A}$ & $95^{\circ} \mathrm{C}, 1 \mathrm{~min}$ & 30 & $95^{\circ} \mathrm{C}, 15 \mathrm{sec}$ & $62^{\circ} \mathrm{C}, 2 \mathrm{~min}$ & $72^{\circ} \mathrm{C}, 40 \mathrm{sec}$ & $72^{\circ} \mathrm{C}, 10 \mathrm{~min}$ \\
\hline $\operatorname{tcd} \mathrm{B}$ & $95^{\circ} \mathrm{C}, 1 \mathrm{~min}$ & 30 & $95^{\circ} \mathrm{C}, 20 \mathrm{sec}$ & $55^{\circ} \mathrm{C}, 30 \mathrm{sec}$ & $60^{\circ} \mathrm{C}, 2 \mathrm{~min}$ & $72^{\circ} \mathrm{C}, 10 \mathrm{~min}$ \\
\hline $\operatorname{cdtA} / \mathrm{cdtB}$ & $94^{\circ} \mathrm{C}, 1 \mathrm{~min}$ & 30 & $94^{\circ} \mathrm{C}, 45 \mathrm{sec}$ & $52^{\circ} \mathrm{C}, 1 \mathrm{~min}$ & $72^{\circ} \mathrm{C}, 80 \mathrm{sec}$ & $72^{\circ} \mathrm{C}, 10 \mathrm{~min}$ \\
\hline
\end{tabular}

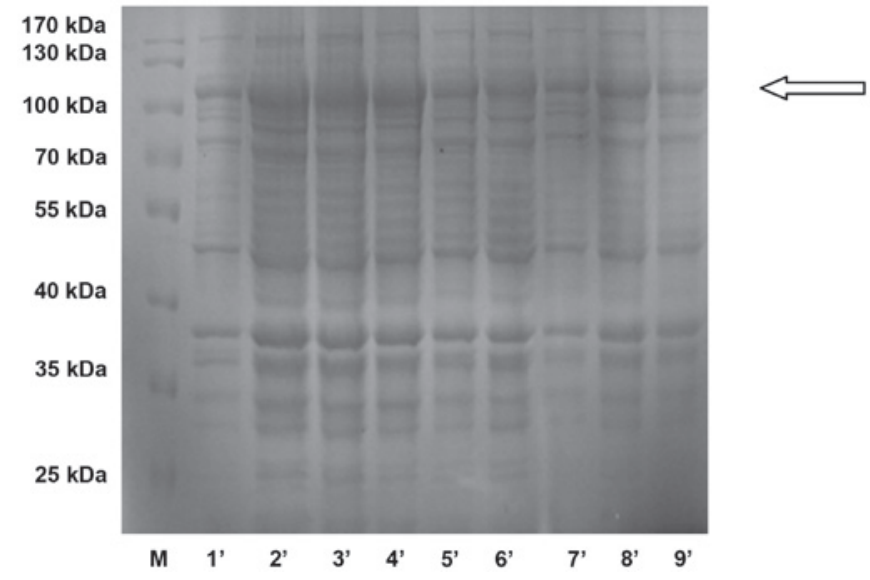

Figure 1. Expression of purified recombinant GST-CDB3 protein in Escherichia coli was analyzed using 10\% SDS-PAGE. The proteins were visualized by Coomassie Blue R-250 staining. Lane 1, protein molecular weight marker; Lane 2, purified GST-CDB3 recombinant protein; Lane 3, molecular size. M, protein molecular weight marker; 1', A1B1C1D1; 2', A1B2C2D2; 3', A1B3C3D3; 4', A2B1C2D3; 5', A2B2C3D1; 6', A2B3C1D2; 7', A3B1C3D2; 8', A3B2C1D3; and 9', A3B3C2D1. A was the concentration of IPTG (mmol/l); B was the induction time (h); C was the concentration of bacteria (OD 600); D was induction temperature $\left({ }^{\circ} \mathrm{C}\right) .1,2,3$ was the level of each, as shown in Table 1. GST, glutathione $\mathrm{S}$ transferase.

China), $1 \mu \mathrm{l}$ each primer (10 $\mu \mathrm{mol} / \mathrm{l}), 8.5 \mu \mathrm{l}$ water and $2 \mu \mathrm{l}$ DNA. The reaction conditions of PCR are shown in Table III. Gels were run under standard conditions on $1.0 \%$ agarose for $25 \mathrm{~min}$ at $100 \mathrm{~V}$, using a 100-2,000 bp ladder (Fermentas, Pittsburgh. PA, USA) as size standard and stained with ethidium bromide for visualization.

\section{Results}

Expression of GST-CDB3 recombinant protein. The optimal conditions for inducing the expression of the GST-CDB3 recombinant protein, which was the optimal concentration of bacteria prior to induction, was $0.8 \mathrm{nM}$, and that of IPTG was $0.6 \mathrm{mM}$, determined using OD600. The optimal induction duration was $12 \mathrm{~h}$ and the induction temperature was $30^{\circ} \mathrm{C}$. The GST-CDB3 recombinant protein was predominantly expressed as a soluble protein.

Purification and identification of GST-CDB3 recombinant protein. The GST-CDB3 recombinant protein was purified using a GST Sefinose ${ }^{\mathrm{TM}}$ kit under native conditions, identified using 10\% SDS-PAGE and subsequently stained using Coomassie Brilliant Blue R250 (Fig. 1). The molecular weight of the GST-CDB3 recombinant protein was $96 \mathrm{kDa}$. The protein was then further identified using western blot analysis with anti-GST tag antibody (Fig. 2). The recombinant protein concentration was $0.89 \mathrm{mg} / \mathrm{ml}$.

Preparation of anti- $C D B 3 m A b$. In the present study, the rate of cell fusion was $98.4 \%$ (945/960), and a total of five (1E7B, 1F8D3, 2F8A6, 3B6F1 and 4A4G2) positive hybridoma cell lines stably secreting anti-CDB3 mAb were identified: 1E7B2 IgG1 $(\lambda), 1$ F8D3 $\operatorname{IgM}(\kappa), 2$ F8A6 IgG2a $(\kappa), 3$ B6F1 $\operatorname{IgM}(\lambda)$ and 4A4G2 $\operatorname{IgG} 1(\kappa)$. The titer was assayed using indirect ELISA, obtaining the following dilutions: 1E7B2 $(1: 25,600)$, 1F8D3 (1:12,800), 2F8A6 (1:51,200), 3B6F1 (1:25,600) and 4A4G2 (1:51,200). The 1E7B2, 2F8A6 and 4A4G2 


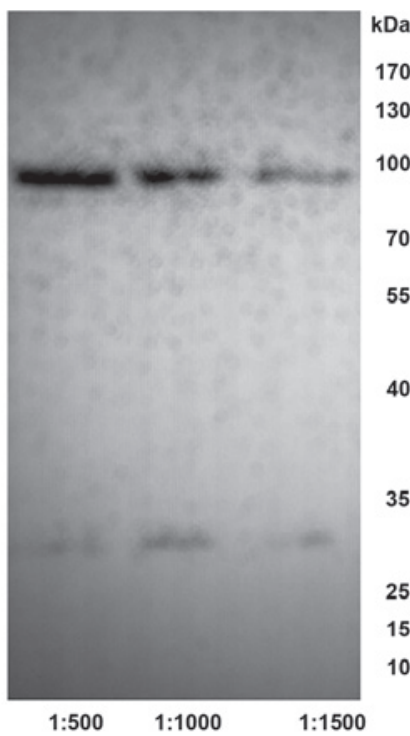

Figure 2. Western blot analysis of purified GST-CDB3 recombinant protein. Identification of proteins was confirmed by western blot analysis using anti-GST tag mAb (lane 1, 1:500; lane 2, 1:1,000; lane 3, 1:2,000). The band appeared most marked when the anti-GST tag mAb was diluted to 1:500. mAb, monoclonal antibody; GST, glutathione $\mathrm{S}$ transferase.

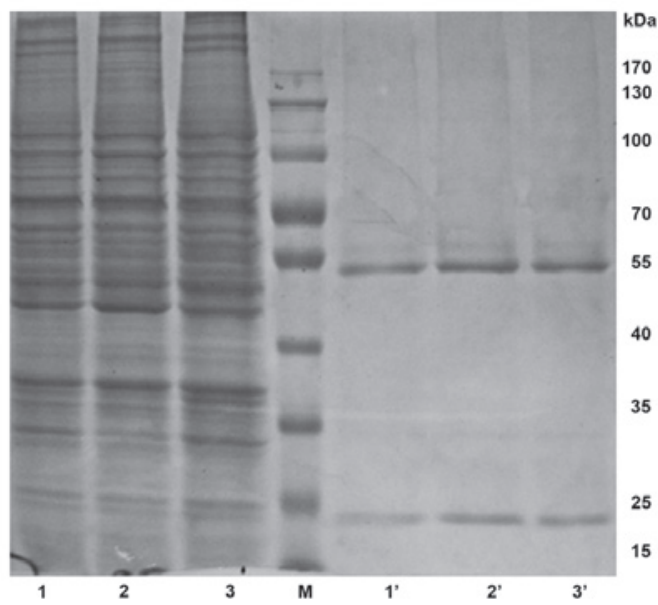

Figure 3. Purification of anti-CDB3 in mouse ascites was analyzed using $10 \%$ SDS-PAGE. The proteins were visualized by Coomassie Blue R-250 staining. Lane 1, ascitic fluid containing 1E7B2 $\mathrm{mAb}$; lane 2, ascitic fluid containing 2F8A6 mAb; lane 3, ascitic fluid containing 4A4G2 mAb; M, protein molecular weight marker; lane 1', purified 1E7B2 mAb; lane 2', purified 2F8A6 mAb; lane 3', purified 4A4G2 mAb. mAb, monoclonal antibody; $\mathrm{CDB} 3$, receptor binding region of Clostridium difficile toxin B.

mAbs were successfully purified by bitterness-ammonium sulfate and protein $\mathrm{G}$ agarose gel electrophoresis. Following dialyzation and condensation, the purity was identified using $10 \%$ SDS-PAGE, with a purification of $>90 \%$ (Fig. 3), and the concentrations of the mAbs were $27.30 \mu \mathrm{g} / \mathrm{ml}, 64.37 \mu \mathrm{g} / \mathrm{ml}$ and $37.36 \mu \mathrm{g} / \mathrm{ml}$, respectively. The molecular weight was $\sim 160 \mathrm{kDa}$.

Affinity of anti-CDB3 $\mathrm{mAb}$. The relative affinities of the mAbs were defined by the antibody concentration at which the OD value reached half the maximal signal at the plateau stage of antigen-antibody binding. The order of relative affinity of the three selected mAbs were 4A4G2, 2F8A6, 1E7B2 (Fig. 4).

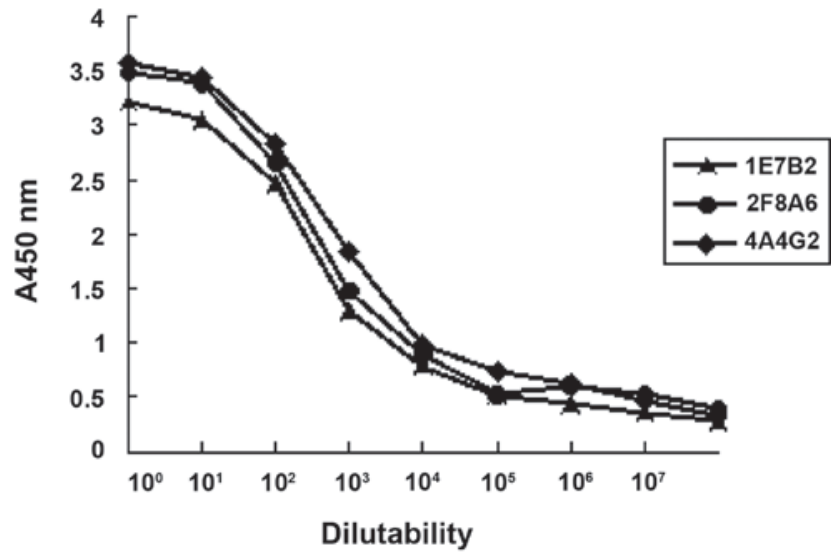

Figure 4. Relative affinities of purified anti-receptor binding region of Clostridium difficile toxin B mAbs were analyzed using an indirect ELISA assay of the serially diluted mAbs. mAbs, monoclonal antibodies. The relative affinities of the $\mathrm{mAbs}$ were defined by the antibody concentration at which the optical density value reached half the maximal signal at the plateau stage of antigen-antibody binding.

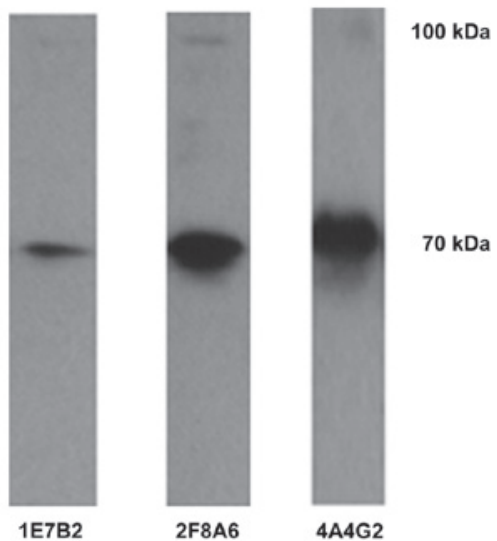

Figure 5. Western blot analysis of the purified 1E7B2, 2F8A6, 4A4G2 anti-receptor binding region of Clostridium difficile toxin $\mathrm{B}$ monoclonal antibodies. Western blotting results demonstrated that the 1E7B2, 2F8A6 and 4A4G2 anti-CDB3 mAbs reacted specifically to the large unit of the GST-CDB3 recombinant protein cleaved by thrombin (molecular weight, $\sim 70 \mathrm{kDa}$ ) and the uncleaved GST-CDB3 recombinant protein (molecular weight, $\sim 100 \mathrm{kDa}$ ), however, no reaction with the tagged protein GST was observed (molecular weight, $\sim 26 \mathrm{kDa}$ ).

Specificity of anti-CDB3 $m A b$. Western blotting results demonstrated that the 1E7B2, 2F8A6 and 4A4G2 anti-CDB3 mAbs reacted specifically to the large unit of the GST-CDB3 recombinant protein cleaved by thrombin (molecular weight, $\sim 70 \mathrm{kDa}$ ) and the uncleaved GST-CDB3 recombinant protein (molecular weight, $\sim 100 \mathrm{kDa}$ ), however, no reaction with the tagged protein GST was observed (molecular weight, $\sim 26 \mathrm{kDa}$ ) (Fig. 5).

Establishment and optimization of ds-ELISA. The anti-CDB3 mAb (4A4G2) was successfully labeled with HRP by modified sodium periodate oxidation. The ds-ELISA was and the optimal working concentration of capture antibody and HRP-labeled $\mathrm{mAb}$ were demonstrated to be $20 \mu \mathrm{g} / \mathrm{ml}$ and 1:400, respectively, as determined using chessboard titration. 
Detection of TcdB in clinical stool samples using ds-ELISA. Of the 15 specimens of $\mathrm{A}^{+} \mathrm{B}^{+}$-type $C$. difficile, 11 were positive for TcdB (73.33\%), detected using ds-ELISA, 13 of the $15 \mathrm{~A}^{-} \mathrm{B}^{+}$-type $C$. difficile samples were positive for TcdB (86.67\%) and all of the 15 C. difficile specimens were negative for TcdB.

\section{Discussion}

Rapid and accurate diagnosis of CDI is essential for improving the outcomes of patients and for reducing horizontal transmission in health care facilities. There are several types of laboratory assessments aimed at detecting pathogens and their toxins in diarrheal fecal specimens, each with their own qualities and limitations. However, an optimal test for the diagnosis of $C$. difficile-associated diseases remains to be established $(34,35)$. Curry $(36)$ reported that the 'diagnosis of CDI remains one of the most vexing difficulties for hospital microbiology laboratories', due to the absence of a single accepted gold standard. For several years, the cell culture cytotoxicity neutralization assay (CCNA) was regarded as the standard method for the diagnosis of CDI (34) due to its correlation with PMC with a specificity $>97 \%$, and its ability to detect toxins in the stool as levels as low as $10 \mathrm{pg}$. However, the CCNA assay is expensive, lacks standardization among laboratories, requires advanced skills and cell culture facilities and has a $24-48 \mathrm{~h}$ turn around period. Several studies have reported toxigenic culture (TC) as the method of choice for the diagnosis of CDI, and is suggested to be the most sensitive method for CDI detection $(34,35,36)$. Compared with TC, CCNA has only $67-79 \%$ sensitivity (36). The Society for Healthcare Epidemiology of America and the Infectious Diseases Society of America 2010 guidelines note that 'the sensitivity and specificity of stool culture followed by identification of a toxigenic isolate, as performed by an experienced laboratory provides the standard against which other clinical tests should be compared' (3). However, this method is slow and laborious, often requires 48-72 h to complete and, therefore, is unlikely to be used in clinical laboratories as the standard method for CDI diagnosis. Furthermore, successfully culturing C. difficile-producing toxin without detection of toxin in the diarrheal stool specimens has not been associated with poorer clinical outcomes, compared with stools negative for toxigenic C. difficile (35). Nucleic acid amplification tests (NAATs) are the most recent methods used for the detection of $C$. difficile. Available NAATs for the identification of $C$. difficile genes are PCR, real-time PCR, and loop-mediated isothermal amplification (37). These assessments detect the chromosomal genes encoding TcdA and TcdB, or the toxin regulatory gene directly from stool samples (38); however, despite detecting the toxin gene, they do not detect the toxin in stool samples, raising concerns over accurate diagnosis in asymptomatic carriers. In addition, the use of PCRs may increase CDI incidence rates by $>50 \%$ (39). A glutamate dehydrogenase antigen assay may be used as a rapid screening method for the presence of $C$. difficile in stools. The assessment is fast (15-45 min), convenient, inexpensive and sensitive, however, it only documents the presence of $C$. difficile, not the presence of toxigenic strains ( $20 \%$ of $C$. difficile strains do not produce toxin) or the presence of toxin in stool (40). Commercial rapid enzyme immunoassays have been the most widely used diagnostic assessment for the detection of TcdA and TcdB due to the fact that they are technically simple to perform, provide rapid (same day) results and are relatively inexpensive (34); however, they may lead to more false-positive test results, compared with the cytotoxicity assay, as the polyclonal antibodies against TcdA and $\mathrm{TcdB}$ used in immunoassays may target other antigens at the same time (41). These limitations may be solved with the use of mAbs, as they can not only improve the specificity of the method, but also decrease the number of false positive results.

$\mathrm{A}^{-} \mathrm{B}^{+} C$. difficile strains causing severe infections and outbreaks have been reported to have increased significantly increased. The prevalence of $\mathrm{A}^{-} \mathrm{B}^{+}$strains among $\mathrm{CDI}$ isolates varies depending on the country; in the majority of Europe and in North America, the prevalence of $\mathrm{A}^{-} \mathrm{B}^{+}$strains has been reported to be only $0.2-8 \%(8,42)$, however, a report from Shanghai revealed that $\mathrm{A}^{-} \mathrm{B}^{+}$strains were responsible for $33.3 \%$ of all CDI cases in China (19), which suggests that $\mathrm{A}^{-} \mathrm{B}^{+}$strains are more prevalent in Asia. TcdB is organized into four distinct structural domains (43): The N-terminal glucosyltransferase domain (residues 1-543), the cysteine protease domain (residues 544-807), the membrane translocation (residues 808-1850) and the C-terminal oligopeptide repeat domain (residues 1851-2366). The short, homologous regions, termed combined repetitive oligopeptides, found in $\mathrm{TcdB}$ are more divergent and less frequent than those found in TcdA (43). TcdB is divided into three fragments, which are separately expressed: CDB1 (amino acids 1-546) contains the catalytic domain; CDB2 (amino acids 901-1750) harbors the putative transmembrane domain; and CDB3 (amino acids 1751-2366) is thought to be the receptor binding domain. Von Eichel-Streiber et al (44) demonstrated that anti-CDB3 exhibited a marked reaction with CDB3 and a weak reaction with CDB1, but not with $\mathrm{CDB} 2$, concluding that the receptor CDB3 binding domain, harboring repetitive peptide domains, was the most antigenic region of the toxin.

The present study successfully established five hybridoma cell lines (1E7B, 1F8D3, 2F8A6, 3B6F1 and 4A4G2), which stably secreted anti-CDB3 mAb, by immunizing BALB/c mice with the GST-CDB3 recombinant protein, which was characterized using indirect ELISA and western blotting. The IgG isotype was predominant [1E7B2 $\operatorname{IgG} 1(\lambda), 2 \mathrm{~F} 8 \mathrm{~A} 6 \operatorname{IgG} 2 \mathrm{a}(\kappa)$ and 4A4G2 IgG1 (א)]. Indirect ELISA demonstrated that the 2F8A6 and 4A4G2 mAbs exhibited high titers of specific binding affinities for $\mathrm{CDB} 3$. Western blotting revealed that the 2F8A6 and 4A4G2 mAbs specifically recognized the CDB3 protein. Therefore, the purified 4A4G2 mAb was labeled with HRP and selected as the detection antibody, and the purified 2F8A6 mAb was selected as the coated antibody to establish a ds-ELISA for the detection of TcdB in clinical diarrhea stool samples. The concentration of the coated antibody was determined as $20 \mu \mathrm{g} / \mathrm{ml}$, and the optimal working concentration of HRP-labeled mAb was 1:400, determined using the chessboard titration method in ds-ELISA. To the best of our knowledge, the present study is the first to describe a ds-ELISA using monospecific antibody as a capture antibody, and $\mathrm{mAb}$ as a detection antibody. This type of ds-ELISA offers distinct advantages: The antibodies utilized, including secondary antibodies, are homogeneous, with specificity for CDB3 and are also less likely to interact with closely associated proteins. 
Cross-reactivity of secondary antibodies is also eliminated. The results of the present study indicated that the sensitivity of the ds-ELISA was $73.33 \%$ to $\mathrm{A}^{-} \mathrm{B}^{+}$toxigenic $C$. difficile strains and $86.67 \%$ to $\mathrm{A}^{-} \mathrm{B}^{+}$toxigenic $C$. difficile strains, with a specificity of $100 \%$ overall.

The isolation of $\mathrm{A}^{-} \mathrm{B}^{+} C$. difficile strains producing TcdB, but not TcdA, are widespread, and are more frequent in east Asian countries. A diagnostic method capable of rapidly detecting the presence of $\mathrm{TcdB}$ is required for use in microbiological laboratories in order to control these strains of C. difficile, however, no diagnostic reagents have been available in China. The rapid diagnosis of $C$. difficile is important and guides the treatment and control of nosocomial spread of infection. To the best of our knowledge, the present study is the first to develop novel mAbs specific to CDB3, and a ds-ELISA kit with high specificity and sensitivity for the rapid detection of TcdB was established. These provide useful tools for the diagnosis of TcdB in CDI.

\section{Acknowledgements}

The present study was supported by funding from the Research Fund Project of the Health Department of the Hunan Province, China (grant no. 1132).

\section{References}

1. Hall IC and O'Toole E: Intestinal flora in newborn infants with a description of a new pathogenic anaerobe. Am J Dis Child 49: 390-402, 1935.

2. George WL, Sutter VL, Goldstein EJ, Ludwig SL and Finegold SM: Aetiology of antimicrobial-agent-associated colitis. Lancet 1: 802-803, 1978.

3. Cohen SH, Gerding DN, Johnson S, Kelly CP, Loo VG, McDonald LC, Pepin J and Wilcox MH; Society for Healthcare Epidemiology of America; Infectious Diseases Society of America: Clinical practice guidelines for Clostridium difficile infection in adults: 2010 update by the society for healthcare epidemiology of America (SHEA) and the infectious diseases society of America (IDSA). Infect Control Hosp Epidemiol 131: 431-455, 2010.

4. Kelly CP: Current strategies for management of initial Clostridium difficile infection. J Hosp Med 7 (Supple 3): S5-S10, 2012.

5. Miller M, Gravel D, Mulvey M, Taylor G, Boyd D, Simor A, Gardam M, McGeer A, Hutchinson J, Moore D, et al: Health care-associated Clostridium difficile infection in Canada: Patient age and infecting strain type are highly predictive of severe outcome and mortality. Clin Infect Dis 50: 194-201, 2010.

6. Kelly CP and LaMont JT: Clostridium difficile - more difficult than ever. N Engl J Med 359: 1932-1940, 2008.

7. Khanna S and Pardi DS: The growing incidence and severity of Clostridium difficile infection in inpatient and outpatient settings. Expert Rev Gastroenterol Hepatol 4: 409-416, 2010.

8. Bauer MP, Notermans DW, van Benthem BH, Brazier JS, Wilcox MH, Rupnik M, Monnet DL, van Dissel JT and Kuijper EJ; ECDIS Study Group: Clostridium difficile infection in Europe: A hospital-based survey. Lancet 377: 63-73, 2011.

9. Gilca R., Hubert B, Fortin E, Gaulin C and Dionne M: Epidemiological patterns and hospital characteristics associated with increased incidence of Clostridium difficile infection in Quebec, Canada, 1998-2006. Infect Control Hosp Epidemiol 31: 939-947, 2010.

10. Barbut F, Jones G and Eckert C: Epidemiology and control of Clostridium difficile infections in healthcare settings: An update. Curr Opin Infect Dis 24: 370-376, 2011.

11. Kuijper EJ, Coignard B and Tüll P, ; ESCMID Study Group for Clostridium difficile; EU Member States; European Centre for Disease Prevention and Control: Emergence of Clostridium difficile-associated disease in North America and Europe. Clin Microbiol Infect 12 (Suppl 6): 2-18, 2006.
12. Kutty PK, Woods CW, Sena AC, Benoit SR, Naggie S, Frederick J, Evans S, Engel J and McDonald LC: Risk factors for and estimated incidence of community-associated Clostridium difficile infection, North Carolina, USA. Emerg Infect Dis 16: 197-204, 2010.

13. Hall AC, Curns AT, McDonald LC, Parashar UD and Lopman BA.: The roles of Clostridium difficile and norovirus among gastroenteritis-associated deaths in the United States, 1997-2007. Clin Infect Dis 55: 216-223, 2012

14. Khanna S and Pardi DS: Clostridium difficile infection: New insights into management. Mayo Clin Proc 87: 1106-1117, 2012.

15. McDonald LC, Lessa F, Sievert D; Centers for Disease Control and Prevention (CDC): Vital signs: Preventing Clostridium difficile infections. MMWR Morb Mortal Wkly Rep 61: 157-162, 2012.

16. Miller BA, Chen LF, Sexton DJ and Anderson DJ: Comparison of the burdens of hospital-onset, healthcare facility-associated Clostridium difficile infection and of healthcare-associated infection due to methicillin-resistant Staphylococcus aureus in community hospitals. Infect Control Hosp Epidemiol 32: 387-390, 2011.

17. Kuehne SA, Cartman ST, Heap JT, Kelly ML, Cockayne A and Minton NP: The role of toxin A and toxin B in Clostridium difficile infection. Nature 467:711-713, 2010.

18. Goorhuis A, Legaria MC, van den Berg RJ, Harmanus C, Klaassen CH,Brazier JS,Lumelsky G and Kuijper EJ: Application of multiple-locus variable-number tandem-repeat analysis to determine clonal spread of toxin A-negative Clostridium difficile in a general hospital in Buenos Aires, Argentina. Clin Microbiol Infect 15: 1080-1086, 2009.

19. Huang H, Wu S, Wang M, Zhang Y, Fang H, Palmgren AC, Weintraub A and Nord CE: Clostridium difficile infections in a Shanghai hospital: Antimicrobial resistance, toxin profiles and ribotypes. Int J Antimicrob Agents 33: 339-342, 2009.

20. Lyerly DM, Krivan HC and Wilkins TD: Clostridium difficile: Its disease and toxins. Clin Microbiol Rev 1: 1-18, 1988.

21. Kim H, Riley TV, Kim M, Kim CK, Yong D, Lee K, Chong $\mathrm{Y}$ and Park JW: Increasing prevalence of toxin A-negative, toxin B-positive isolates of Clostridium difficile in Korea: Impact on laboratory diagnosis. J Clin Microbiol 46: 1116-1117, 2008.

22. Iwashima Y, Nakamura A, Kato H, Kato H, Wakimoto Y, Wakiyama N, Kaji C and Ueda R: A retrospective study of the epidemiology of Clostridium difficile infection at a University Hospital in Japan: Genotypic features of the isolates and clinical characteristics of the patients. J Infect Chemother 16: 329-333, 2010.

23. Elliott B, Squire MM, Thean S, Chang BJ, Brazier JS, Rupnik M and Riley TV: New types of toxin A-negative, toxin B-positive strains among clinical isolates of Clostridium difficile in Australia. J Med Microbiol 60: 1108-1111, 2011.

24. Pruitt RN and Lacy DB: Toward a structural understanding of Clostridium difficile toxins A and B. Front. Cell Infect Microbiol 2: 28,2012.

25. Komatsu M, Kato H, Aihara M, Shimakawa K, Iwasaki M, Nagasaka Y, Fukuda S, Matsuo S, Arakawa Y, Watanabe M, et al: High frequency of antibiotic-associated diarrhea due to toxin A-negative, toxin B-positive Clostridium difficile in a hospital in Japan and risk factors for infection. Eur J Clin Microbiol Infect Dis 22: 525-529, 2003.

26. Shin BM, Kuak EY, Yoo SJ Shin WC and Yoo HM: Emerging toxin A-B+ variant strain of Clostridium difficile responsible for pseudomembranous colitis at a tertiary care hospital in Korea. Diagn Microbiol Infect Dis 60: 333-337, 2008.

27. Hadji-Ghasemi F, Gharagozlou S, Ghods R, Roohi A, Khoshnoodi J and Shokri F: Generation and characterization of a mouse monoclonal antibody with specificity similar to staphylococcal protein A (SPA). Hybrid Hybridomics 22: 33-39, 2003.

28. Hajighasemi F, Khoshnoodi J and Shokri F: Development of two murine monoclonal antibodies recognizing human nG1m(a)-like isoallotypic markers. Hybridoma (Larchmt) 27: 473-479, 2008.

29. Hajighasemi F, Gharagozlou S, Ghods R, Khoshnoodi J and Shokri F: Private idiotypes located on light and heavy chains of human myeloma proteins characterized by monoclonal antibodies. Hybridoma (Larchmt) 25: 329-335, 2006.

30. Singh RP, Bandyopadhyay SK, Sreenivasa BP, and Dhar P: Production and characterization of monoclonal antibodies to peste des petits ruminants (PPR) virus. Vet Res Commun 28: 623-639, 2004. 
31. Harlow ED and Lane D: Antibodies: A Laboratory Manual. Cold Spring Harbor Laboratory, New York, pp148-242, 1988.

32. Hajighasemi F, Saboor-Yaraghi AA and Shokri F: Measurement of affinity constant of anti-human $\mathrm{IgG}$ monoclonal antibodies by an Elisa-based method. Iran Immunol 1: 154-161, 2004.

33. Jie Y, Luo HB and Lu DY: Modern microbiological techology and its application 1st edition, people health press. Beijing p173-183, 1997.

34. Curry S: Clostridium difficile. Clin Lab Med 30: 329-342, 2010.

35. Crobach MJ, Dekkers OM, Wilcox MH, and Kuijper EJ European Society of Clinical Microbiology and Infectious Diseases (ESCMID): Data review and recommendations for diagnosing Clostridium difficile-infection (CDI). Clin Microbio Infect 15: 1053-1066, 2009.

36. Wilcox MH: Overcoming barriers to effective recognition and diagnosis of Clostridium difficile infection. Clin Microbiol Infect 18 (Suppl 6): 13-20, 2012.

37. Boyanton BL, Sural P,Loomis CR,Pesta C, Gonzalez-Krellwitz L, Robinson-Dunn B and Riska P: Loop-mediated isothermal amplification compared to real-time PCR and enzyme immunoassay for toxigenic Clostridium difficile detection. J Clin Microbiol 50: 640-645, 2012.

38. Deshpande A, Pasupuleti V, Rolston DD, Jain A, Deshpande N, Pant $\mathrm{C}$ and Hernandez AV: Diagnostic accuracy of realtime polymerase chain reaction in detection of Clostridium difficile in the stool samples of patients with suspected Clostridium difficile infection: A metaanalysis. Clin Infect Dis 53: e81-e90, 2011.
39. Longtin Y, Trottier S, Brochu G, Paquet-Bolduc B, Garenc C, Loungnarath V, Beaulieu C, Goulet D and Longtin J: Impact of the type of diagnostic assay on Clostridium difficile infection and complication rates in a mandatory reporting program. Clin Infect Dis 56: 67-73, 2013.

40. Wilkins TD and Lyerly DM: Clostridium difficile testing: After 20 years, still challenging. J Clin Microbiol 41: 531-534, 2003.

41. Planche T, Aghaizu A, Holliman R, Riley P, Poloniecki J, Breathnach A and Krishna S: Diagnosis of Clostridium difficile infection by toxin detection kits: A systematic review. Lancet Infect Dis 8: 777-784, 2008.

42. Cheknis AK, Sambol SP, Davidson DM, Nagaro KJ, Mancini MC, Hidalgo-Arroyo GA, Brazier JS, Johnson S and Gerding DN: Distribution of Clostridium difficile strains from a North American, European and Australian trial of treatment for Clostridium difficile infections: 2005-2007. Anaerobe 15: 230-233, 2009.

43. Albesa-Jové D, Bertrand T, Carpenter EP, Swain GV, Lim J, Zhang J, Haire LF, Vasisht N, Braun V, Lange A, et al: Four distinct structural domains in Clostridium difficile toxin B visualized using SAXS. J Mol Biol 396: 1260-1270, 2010.

44. von Eichel-Streiber C, Laufenberg-Feldmann R, Sartingen S, Schulze J and Sauerborn M: Comparative sequence analysis of the Clostridium difficile toxins A and B. Mol Gen Genet 233: 260-268,1992. 